Навитскайте Сандра

магистрант

Шиирас Шарунас Альфонсович

д-р пед. наук, доцент

Литовский университет спорта

г. Каунас, Литовская Республика

DOI $10.21661 / r-508776$

\title{
SOCIAL SKILLS OF THE SCHOOLCHILDREN ATTENDING PHYSICAL EDUCATIONS LESSONS
}

Аннотация: за несколько последних лет исследователи уделяют все больше и больше внимание на коммуникативные навыки детей дошкольного возраста, но все ещзе недостаточное внимание уделяется исследованию, касаемо коммуникативных навыков дошкольников, посещуающих уроки физической культурыл. Авторы подчеркивают, что именно по этой причине, статья посвящена обсуждению уровня коммуникативных навыков на уроках физической культуры и значению коммуникативных навыков дошкольников.

Ключевые слова: коммуникативные навыки, коммуникативные навыки, возникающие в определенной ситуащии, дети дошкольного возраста.

Abstract: in recent years researchers are paying more and more attention to the social skills of schoolchildren but we still lack research works on the social skills of the schoolchildren attending PE classes. the authors outlines that for this reason, the level of the social skills in the PE lessons and the importance of social skills for the schoolchildren will be discussed in the article.

Keywords: social skills, social situational skills, shoolchildren.

Development of social skills is important because in the contemporary school not enough attention is paid to the harmonious spread of the young personality. More and more schools are paying more attention to the development of social skills in PE classes. 
According to Hellison, 2011 social skills are important as a dynamic PE lesson today opens various opportunities to communicate and interact. The researchers (Weisberg, Domitrovich, Gullotta, 2015) state that schoolchildren who possess enough social skills, can apply the knowledge more effectively, they also tend to control their emotions, can better reach their aims, can create better, and are not afraid to take responsibilities. For that reason, social skills acquired at school can be successfully transformed to the other spheres of life. Sports activities are very popular with teenagers and due to that reason it is thought that social skills can successfully be developed in sports. (Akelaitis, 2016). The research done can prove that in PE lessons it is possible successfully develop various social skills (Hellison, Martinek, 2006), honorable behavior during competitions (Vidoni, Ward, 2009), successful team work (Hunter, 2006) and cooperation (Merkel, 2013). Newer research (Akelaitis, 2016) the negative consequences which appear when social skills of schoolchildren are not enough developed. Such scientific discussions encourage to organize the research of social skills in PE classes.

Organising of the research. 63 schoolchildren (boys and girls) aged 12-13 years, attending classes 5-6, participated in the research. The participants were chosen in the most convenient way. The research took place in the secondary schools and gymnasiums of Marijampole district. The research was carried on in PE lessons. The questionnaire of E. Gambril (1995) was used to assess situational social skills. This questionnaire helps to evaluate the level of situational social skills in PE lessons.

Results. The research results prove that situational social skills of boys and girls differ and the difference is statistically reliable.

The distribution of schoolchildren (boys and girls) according to the level of situational social skills (in numbers and percentage)

\begin{tabular}{|c|c|c|c|c|c|c|c|c|}
\hline \multirow{3}{*}{ Social skills } & \multirow{3}{*}{ Gender } & \multicolumn{6}{|c|}{ Level } & \multirow{3}{*}{$\frac{\chi^{2}(2)}{p}$} \\
\hline & & \multicolumn{2}{|c|}{ Low } & \multicolumn{2}{|c|}{ Average } & \multicolumn{2}{|c|}{ High } & \\
\hline & & $n$ & $\%$ & $n$ & $\%$ & $n$ & $\%$ & \\
\hline \multirow{2}{*}{ To be able to refuse } & Girls & 10 & 24,4 & 10 & 24,4 & 21 & 51,2 & 3,02 \\
\hline & Boys & 10 & 31,3 & 12 & 37,4 & 10 & 31,3 & $\mathrm{p}>0,05$ \\
\hline \multirow{3}{*}{ To react to remarks* } & Girls & 13 & 31,7 & 20 & 48,8 & 8 & 19,5 & 8,45 \\
\hline & Boys & 4 & 12,5 & 12 & 37,5 & 16 & 50,0 & $p<0,05$ \\
\hline & Girls & 28 & 68,3 & 8 & 19,5 & 5 & 12,2 & 0,68 \\
\hline
\end{tabular}




\begin{tabular}{|l|c|c|c|c|c|c|c|c|}
\hline $\begin{array}{l}\text { To be able to } \\
\text { contradict }\end{array}$ & Boys & 21 & 65,6 & 5 & 15,6 & 6 & 18,8 & $\mathrm{p}>0,05$ \\
\hline \multirow{2}{*}{ To apologise* } & Girls & 2 & 4,9 & 14 & 34,1 & 25 & 61,0 & 11,4 \\
\cline { 2 - 9 } & Boys & 11 & 34,4 & 10 & 31,2 & 11 & 34,4 & $p<0,05$ \\
\hline $\begin{array}{l}\text { To recognise of being } \\
\text { wrong }\end{array}$ & Girls & 8 & 19,5 & 12 & 29,3 & 21 & 51,2 & 0,49 \\
\cline { 2 - 9 } $\begin{array}{l}\text { To be able to enjoy } \\
\text { praise }\end{array}$ & Boys & 5 & 15,6 & 8 & 25,0 & 19 & 59,4 & $\mathrm{p}>0,05$ \\
\hline \multirow{2}{*}{ To ask for help } & Girls & 2 & 4,9 & 14 & 34,1 & 25 & 61,0 & 1,46 \\
\cline { 2 - 9 } To say good words* & 4 & 12,5 & 11 & 34,4 & 17 & 53,1 & $\mathrm{p}>0,05$ \\
\cline { 2 - 9 } & Girls & 6 & 14,6 & 15 & 36,6 & 20 & 48,8 & 6,10 \\
\cline { 2 - 9 } & Goys & 4 & 12,5 & 20 & 62,6 & 7 & 21,9 & $p<0,05$ \\
\hline \multirow{2}{*}{ To tell what one feels } & Boys & 9 & 7,3 & 16 & 39,0 & 22 & 53,7 & 6,81 \\
\cline { 2 - 9 } & Goys & 15 & 36,6 & 10 & 24,4 & 16 & 39,0 & 2,87 \\
\hline
\end{tabular}

Note. ${ }^{*}-p<0,05$ comparing the distribution of schoolchildren between the two groups.

It is possible to state that a higher level of some situational social skills is typical to girls and a part of social skills is typical to boys. For example, girls can easier apologize $(61 \%)$, ask for help $(48,8 \%)$ and say good words $(53,7 \%)$. The girls gave a high assessment to those skills while boys gave a higher level only to the skill react to remarks (50\%). Such skills as to be able to refuse, to be able to contradict, to recognize being wrong and to tell what one feels were equally evaluated by boys and girls.

Conclusions. After analyzing situational skills of schoolchildren, it is possible to state that in the lessons of PE girls more often succeed to apologize, ask for help and say good words, while boys more effectively react to remarks.

\section{Список литературы}

1. Akelaitis, A. (2016). Vyresniojo mokyklinio amžiaus mokinių socialinių emocinių gebėjimų ugdymas per kūno kultūros pamokas. Kaunas: LSU.

2. Gambrill, E. (1995). Assertion skill training, in W. O'Donohue and L. Krasner (eds), Handbook of Psychological Skills training: Clinical Techniques and Applications, Allyn \& Bacon, Boston, pp. 81-117.

3. Hellison, D. (2011). Teaching personal and social responsibility through physical activity. USA: Human Kinetics. 
4. Hellison, D., Martinek, T. (2006). Social and individual responsibility programs. In D. KirkD. Macdonald, M. O'Sullivan Handbook of physical education (pp. 610-626). London: SAGE Publications.

5. Hunter, L. (2006). Research into elementary physical education programs. The Handbook of Physical Education. London: Sage Publications.

6. Merkel, D. L. Youth sport: positive and negative impact on young athletes. Open Access Journal of Sports Medicine. 2013, №4. - P. 151-160.

7. Vidoni, C., Ward, P. (2009). Effects of fair play instruction on student social skills during a middle school sport education unit / Physical Education and Sport Pedagogy. №14(3), - P. 285-310.

8. Weissberg, R. P., Durlak, J. A., Domitrovich, C. E., Gullotta, T. P. (2015). Social and emotional learning: Past, present, and future. In J. A. Durlak, R. P. Weissberg \& T. P. Gullotta (Eds.), Handbook of social and emotional learning: Research and practice. New York: Guilford. 